\title{
AANWINST: EEN SCULPTUUR VAN EEN ZITTENDE LOHAN
}

Eerder dit jaar kon een belangwekkend beeld veilig worden gesteld voor de collectie van de vereniging (afb. 1). Het is zeldzaam dat een dergelijk fraai stuk voor verwerving beschikbaar komt en Vereniging en Rijksmuseum zijn dan ook zeer verheugd de bestaande verzameling Chinese beeldhouwkunst zo aan te kunnen vullen. Bij de afgelopen jaarvergadering is deze sculptuur al aan de leden gepresenteerd; hieronder wordt het beeld verder aan $u$ voorgesteld.

\section{Een zittende lohan}

Een figuur van een zittende man houdt het hoofd geheven, de handen rustend op het opgetrokken linkerbeen, dat over het rechter is geslagen. Het beeld moet oorspronkelijk op een verhoging hebben gezeten: de man zit op een vlak, terwijl de vouwen van zijn monniksgewaad in clegante rondingen en krullen aan de voorkant in een rechte hoek over de rand zijn gedrapeerd. Opvallend is de doordringende blik van de met glas ingelegde ogen in het markant vormgegeven gezicht, met de pregnante, volle lippen (afb. 2).

Het kaalgeschoren hoofd en het kleed vertellen ons dat deze man een boeddhistische monnik is. De langgerekte oorlellen maken verder duidelijk dat dit niet zomaar een figuur in monnikskledij is. Langgerekte oren behoren in het boeddhisme toe aan wezens met een hogere kennis, zoals ook wel monniken, maar vooral aan hogere, bovennatuurlijke wezens als bodhisattva's en boeddha's.' Het is kortom een monnik met bijzondere kwaliteiten, een lohan: een monnik die zich geheel heeft toegelegd op het verkrijgen van de hoogste wijsheid en daartoe als kluizenaar een leven in afzondering leidt. ${ }^{2}$

\section{Lohan}

Een belangrijk streven in het boeddhisme is het ontsnappen aan de eeuwige reeks van wedergeboorten waaraan elk wezen ondergeschikt is. Dat kan door goede daden te doen, maar ook door het bedrijven van ascese; het kan getrapt gaan, in de loop van verschillende levens, maar ook in één leven. Monniken leven dan ook in een gemeenschap met strenge regels, die er op gericht zijn de emoties en verlangens die er toe leiden aan het leven te hechten te laten verdwijnen en hun kennis te vervolmaken.

Afbeelding, (rechts) Lohan, hout met beschildering, China, 13e-14e eeuw, Rijksmuseum, WAK, inv.nr. AK-MAK-1727
Lohan leggen hier een schepje boven op en wijden hun leven er helemaal aan om ver van de maatschappij via meditatie en ascetische praktijken alle emoties kwijt te raken en zich de volmaakte wijsheid eigen te maken. Daartoe leeft een lohan in volstrekte afzondering in veraf gelegen gebieden, in bossen, op bergen, ver van zijn medemens en geheel aan zich zelf overgeleverd. Zo verkrijgt hij zijn vervolmaakte wijsheidenninzicht. ${ }^{3}$ Hijlis wrij vartbegeerte; $50 \mathrm{PM}$ 


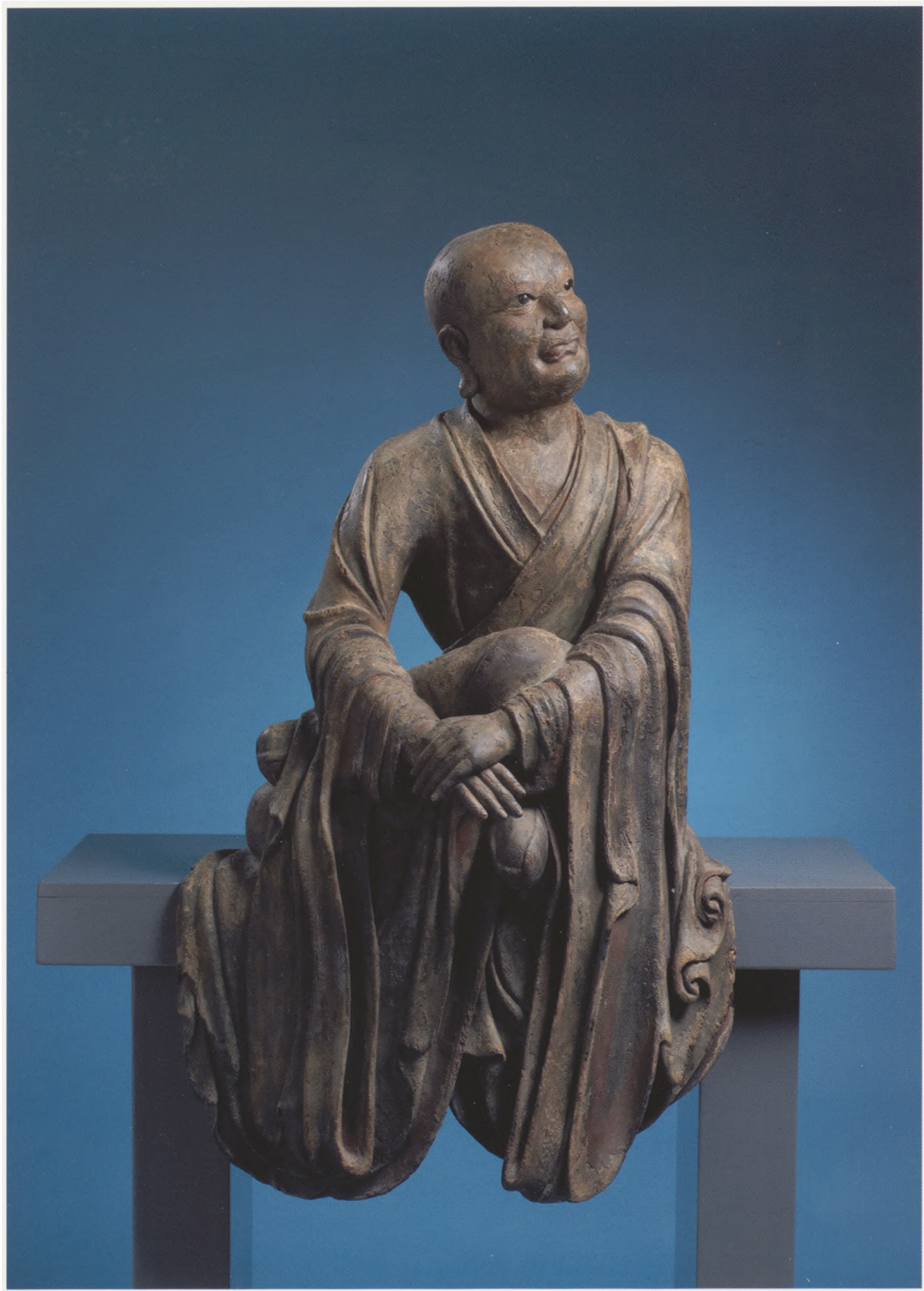


Afbeelding 2

Lohan, detail afb. 1

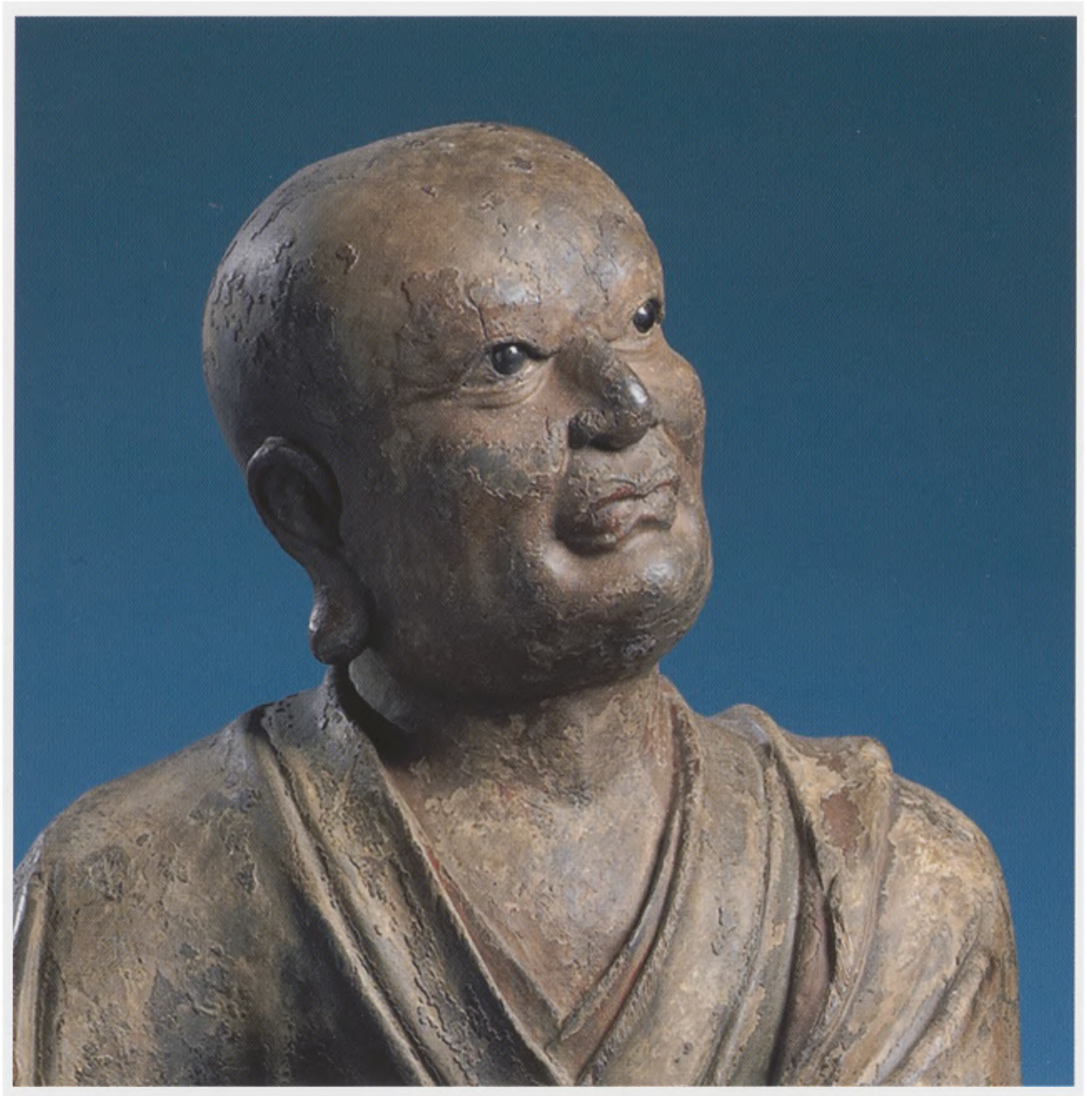

verlangen en onwetendheid. Alle onreinheid is weggewassen en storende mentale emoties als woede, twijfel, begerigheid, domheid en oneerbiedigheid zijn afgeweerd. De taken zijn vervuld, alle lasten zijn afgelegd en alle banden zijn verbroken. $\mathrm{Hij}$ is zo niet meer onderworpen aan het proces van wedergeboorte. ${ }^{4}$

Een lohan beschikt over aanzienlijke en bovennatuurlijke krachten. Zo kan hij wonderen verrichten en zijn zowel zijn gezichtsvermogen als gehoor alomvattend. Verder kan hij de gedachten van iedereen gelijktijdig lezen en heeft hij het vermogen om zich naar believen onmiddellijk overal heen te verplaatsen of van grootte te veranderen. De beeldhouwer van dit beeld heeft die grote innerlijke kracht mooi tot uitdrukking laten komen in de intense blik en de trotse, aandachtige houding.

Toen het boeddhistische concept van de lohan vanuit India in de $4 \mathrm{e}$ tot $6 \mathrm{e}$ eeuw vanuit India naar China kwam, vond het een vruchtbare bodem.

Immers, het begrip van een in afzondering levende asceet in de bergen was al geruime tijd daarvoor in het Chinese taoïstische denken aanwezig. ${ }^{5}$ Ook hier is er sprake van wijze mannen, die zich met dauw en wind voeden in verre bergstreken, een bovenmenselijk hoge leeftijd bereiken en zich bezighouden met magische activiteiten. Het is dan ooknieteverwonderlijkodat elementen 6:50pM 
van de taoïstische asceet en de boeddhistische lohan in China in de loop van de tijd onlosmakelijk vermengd zijn geraakt.

\section{Eén van een groep van 16 of 18}

Binnen de grote groep van lohan is er een groep van 16 'grote' lohan die in het bijzonder vereerd worden. Deze groep wordt beschreven in een sutra die zich situeert op Sri Lanka. ${ }^{6}$ De tekst Da aluohan Nandimiduoluo suo shuo fazhuji (Optekening van de Duur van de Leer uitgesproken door de grote lohan Nandimitra) beschrijft 16 discipelen van de Boeddha, opgetekend uit de mond van een van hen en verhaalt dat de Boeddha hen vlak voor zijn dood de taak had gegeven om de boeddhistische leer te beschermen, totdat hij in de toekomst in de vorm van Maitreya weer terug zou keren. Het vermogen van de lohan om hun leven te rekken en hun andere magische krachten helpen hen bij het bewaken van de leer.

De sutra werd al in de 7e eeuw in het Chinees vertaald, maar de verering van de lohan als groep begon pas tegen het begin van de Song-periode (960-1279) echt tot bloei te komen. In deze tijd ontstonden ook groepen van 16 of 18 beelden van lohan, opgesteld in een rij in de tempel; ook onze lohan maakte ooit deel uit van zo'n groep. Het feit dat er in China, in tegenstelling tot India en Japan, het aantal lohan met twee is uitgebreid, wordt op verschillende manieren verklaard. ${ }^{7}$ Het lijkt samen te hangen met het toevoegen van twee mythische dieren uit het taoïsme, de Witte Tijger en de Groene Draak, samen met twee extra lohan, die dan vaak rijdend op een van de dieren worden afgebeeld. ${ }^{8}$

Het is niet helemaal zeker welke van de 16 of 18 lohan het pas verworven beeld voorstelt. De afbeelding van lohan lijkt niet gestandaardiseerd te zijn; attributen en begeleidende dieren zijn door schilders en beeldhouwers verschillend aan de individuele lohan toegeschreven. Dat gezegd hebbend, is het niet uitgesloten dat het hier gaat om de $15 \mathrm{e}$ lohan, Ajita. In een latere beschrijving van een set schilderingen van 18 lohan uit de vroege $12 \mathrm{e}$ eeuw wordt hij omschreven als 'met zijn hoofd schuin, luisterend naar het lezen van een sutra, met een hemelse, pure blik, als in een staat van samadhi (meditatieve staat van volledige concentratie)'. ${ }^{9}$ Verder beeldt een $18 \mathrm{e}$-eeuws overzichtswerk met afbeeldingen van 500 lohan Ajita eveneens in een luisterende pose af. ${ }^{10}$ Dat vermogen tot volledige aandacht en concentratie is overigens een kwaliteit waar een lohan in het algemeen om bekend staat.

\section{Stijl en datering}

Zoals al aangegeven kwam de belangstelling voor lohan in China in de $10 \mathrm{e}$ eeuw op gang, even voor het begin van de Song-periode in 960. Dat viel samen met een andere ontwikkeling. In de Song-beeldhouwkunst ontwikkelde zich net als in de schilderkunst uit die periode een toenemend realisme. Die trend was al in de voorafgaande Tang-periode (608-906) ingezet, toen lichamen en gezichten al meer en meer realistische trekken meekregen, maar nu werden gelaatstrekken en kleding met een echt individueel karakter uitgebeeld. De toepassing van kristallen ogen, zoals ook de Amsterdamse lohan heeft, is een uiting van dat realisme, en het is ook te zien aan de plooien van het gewaad en de delicaat gevouwen handen. Het eenvoudige monniksgewaad met het onderkleed doet denken aan dat van zen-monniken en dat is

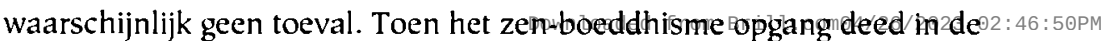


Song-periode gaf dat aanleiding tot het ter nagedachtenis (laten) maken van realistische portretten van leermeesters. Vaak zijn deze geschilderd, maar er zijn ook portretten in de vorm van beelden.

Dit realisme was echter geen exercitie om de werkelijkheid zo natuurgetrouw mogelijk uit te beelden; het was een instrument om de religieuze boodschap beter bij de gelovige over te laten komen. In het geval van de lohan-figuur was het de bedoeling dat men zich er aan spiegelde en er toe aangezet werd om zelf wijsheid en inzicht na te streven.

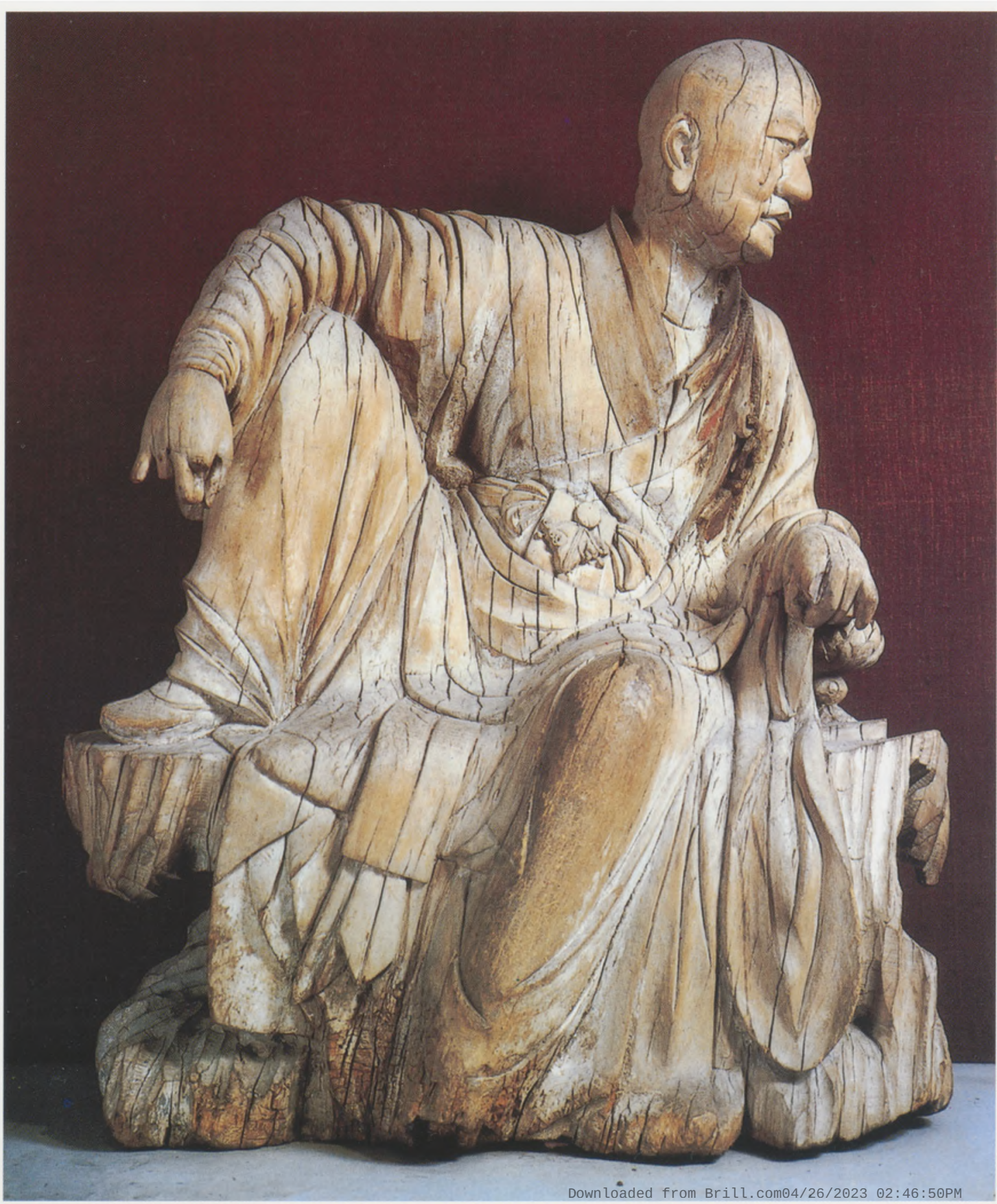


In Westerse musea zijn er in ieder geval drie vergelijkbare houten beelden, die net als de lohan in het Rijksmuseum rond de meter hoog zijn, en die dit functioneel realisme goed laten zien. ${ }^{11}$ De meest vergelijkbare daarvan is in het Victoria \& Albert Museum (afb. 3), die in de $14 \mathrm{e}$ eeuw gedateerd wordt. Hij zit met opgetrokken been leunend op een armsteun, alsof hij in gesprek is met een buurman; wellicht was dit inderdaad het geval in de oorspronkelijke groepering in de tempel. Op dit beeld zijn resten van de rode beschildering nog zichtbaar op de rand van het gewaad bij de borstkas. De plooien zijn vergeleken met de lohan van de Vereniging ietwat meer gestileerd, al kan het

Afbeelding 3 (links) Lohan, hout met resten van beschildering, China, 14e eeuw, Victoria \& Albert Museum, Londen. Uit: Oriental Art in the Victoria Q Albert Museum, Londen, 1992, p. 24. zijn dat met het verlies van de oorspronkelijk beschildering een deel van de detaillering verloren is gegaan.

Wellicht kan onze recente aanwinst iets eerder dan het Londense exemplaar gedateerd worden, al is verder onderzoek nodig om meer informatie te krijgen. Een eerste blik op het beeld heeft geleerd dat het uit tenminste zes blokken hout bestaat. Röntgenonderzoek zou meer gegevens hierover kunnen opleveren en dat geldt uiteraard ook voor de samenstelling van de beschildering. Er lijken meerdere lagen polychromie over een laklaag te zijn aangebracht, een laklaag die weer op een ondergrond van textiel lijkt te zijn bevestigd. De laatste - en wellicht de meest recente laag is een dikke roodbruine, die op zijn beurt weer donker gekleurd is, mogelijk door (wie)rook. Deze donkere kleuring is recentelijk voor het grootste deel verwijderd.

\section{Herkomst}

Het is niet bekend wat de geschiedenis van dit beeld is voordat het in 2004 in Hong Kong werd verworven door de handelaar. Wel is het zo dat deze houten beelden zeer kwetsbare voorwerpen zijn, die bij het niet goed onderhouden van een tempelcomplex gemakkelijk in slechte staat kunnen raken. Gezien de moeilijke periode die tempels in China in de 20e eeuw hebben doorgemaakt en de goede staat waarin het beeld verkeert, is het zeer waarschijnlijk dat het al in de eerste decennia van de eeuw uit zijn oorspronkelijke omgeving is gehaald. Toen was er immers een opleving in de interesse voor Chinese kunst in het buitenland, en werden veel beelden door handelaren in China doorverkocht, hetzij naar anderen in China zelf, of - meestal via handelaren - naar verzamelaars in Europa, de Verenigde Staten en Japan. De houten Guanyin uit de collectie van onze Vereniging is tenslotte ook via die weg naar Nederland gekomen: het werd in de jaren 1920 van een handelaar in Beijing gekocht door een Duitse kunsthandelaar, waarna het via een omweg en een veiling in Parijs weer in Duitse handen terecht kwam, voordat de Vereniging er uiteindelijk in 1939 de hand op wist te leggen. ${ }^{12} \mathrm{Het} z o u$ goed kunnen zijn dat ook deze lohan sinds de vroege 20e eeuw in een of meerdere privé-collecties bewaard is gebleven, al dan niet in China zelf.

\section{Plaats in de collectie}

De verzameling Chinese boeddhistische beeldhouwkunst van onze Vereniging telt een aantal goede stukken, met als onbetwist hoogtepunt de Guanyin uit de $12 \mathrm{e}$ eeuw. Daarnaast is er een reeks van kleine verguld bronzen beeldjes die de ontwikkeling van de 5e tot de $12 \mathrm{e}$ eeuw illustreert, een vroeg Song-periode houten beeld van een staande Guanyin, en twee stenen bodhisattva-figuren uit de $6 \mathrm{e}$ en $8 \mathrm{e}$ eeuw. Hiermee kan de Vereniging,

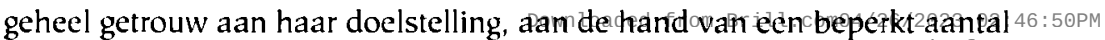


kwalitatief hoogstaande stukken een beknopt overzicht geven van de vroege Chinese boeddhistische beeldhouwkunst tot aan de 12e eeuw.

De verzameling ontbeerde tot nog toe een goede representant van sculptuur uit de latere periodes. Het hier voorgestelde beeld is dan ook een fraaie opvulling van deze lacune: er was bovendien nog geen vergelijkbare lohanfiguur in een Nederlandse collectie.

Met de uitstraling van het markante gezicht, de zelfverzekerde pose en de sierlijke golven van het gewaad is het voor het museumpubliek een aantrekkelijk voorwerp, dat in de toekomstige opstelling van het Paviljoen van het Nieuwe Rijksmuseum een aansprekende rol zal kunnen vervullen. Daar zal hij, net als nu, ongetwijfeld een plaats krijgen in de buurt van de houten Guanyin. Niet elk beeld is opgewassen tegen de nabijheid van zo'n meesterwerk als de Guanyin en het was tekenend voor de kwaliteit van de lohan dat hij die krachtproef met glans wist te doorstaan toen hij de afgelopen zomer in het museum van CODA in Apeldoorn werd opgesteld. Voorwaar een aanwinst.

\section{Noten}

1. In China was een lange oorlel een teken van wijsheid. Een scherp gehoor werd geassocieerd met wijsheid, zoals in Europa een goed ontwikkeld gezichtsvermogen eenzelfde connotatie meekreeg. R. Kent, 'Depictions of the Guardians of the Law: Lohan Painting in China', Latter Days of The Law: Images of Chinese Buddhism 8501850, Spencer Museum of Art, Lawrence en University of Hawaii Press, Honolulu, 1994, p. 187.

2. Sanskriet, arhat of arhant; Japans, rakan. Zie voor informatie over lohan: Kent, op.cit. (noot 1), pp. 183-213; M.W. de Visser, The Arhats in China And Japan, Berlijn, 1923; T. Watters, 'The Eighteen Lohan of Chinese Buddhist Temples', in: The Journal of the Royal Asiatic Society, 1898/04, pp. 329-347. Met dank aan Pauline Lunsingh Scheurleer voor haar opmerkingen en aanvullingen.

3. Het hiernavolgende is ontleend aan De Visser, op.cit. (noot 2), pp. 8-12.

4. Tussen de lohan is er onderscheid te maken in de mate van gereedheid om het Nirvana te betreden; lohan van lager niveau komen nog niet in aanmerking. Er zijn verder twee stadia van het Nirvana, waarvan de eerste reeds door de lohan is bereikt. Het tweede en laatste stadium wordt bij het sterven ingegaan, dat bij lohan uitgesteld is, aangezien zijn leven in zeer grote mate verlengd is. Zie de Visser, op.cit. (noot 2), pp. $11,12$.

5. Zie bijvoorbeeld S. Little, Taoism and the Arts of China, Chicago, 2000, pp. 313-335.

6. Zie voor een weergave van de inhoud hiervan Kent, op.cit. (noot 2), p. 184.

7. Watters, p. 346 en de Visser, 132, op.cit. (noot 2) wijzen op de toevoeging van de lohan Nandimitra en Pindola in veel tempels, waarbij Pindola dan twee maal vertegenwoordigd is in de groep.

8. Kent, op.cit. (noot 2), pp. 187, 188.

9. De Visser, op.cit. (noot 2), pp. 122, 123.

10. Huitu wubai luohan, Peking, 1992.

11. In het Royal Ontario Museum in Toronto, het Seattle Art Museum en het Victoria \& Albert Museum in Londen.

12. Zie A. Lorne, P. Rösch en P. Lunsingh Scheurleer, 'The Chinese Wooden Sculpture of Guanyin. New technical and art historical insights', in: Bulletin van het Rijksmuseum 50/3 (2002), p. 367, 368, 379-381. 